\title{
Influence of El Niño 2015/2016 on Climate Variability and Production of Main Crops in Langkat Regency
}

\author{
Khadijah El Ramija ${ }^{1}$, Ayi Sudrajat ${ }^{2}$, Hendri Irwandi ${ }^{2}$ and Joko Yulianto Ariantono ${ }^{2}$ \\ ${ }^{1}$ Assessment Institute of Agricultural Technology of North Sumatera, Jalan AH Nasution 1B, Medan, Indonesia 20143 \\ 2Deli Serdang Climatological Station, Jalan Meteorologi Raya 17, Deli Serdang, Indonesia 20371
}

\section{ARTICLEINFO}

\section{Received}

30 October 2019

\section{Revised}

19 April 2021

\section{Accepted for Publication}

28 July 2021

\section{Published}

21 October 2021

doi: 10.29244/j.agromet.35.2.98-107

\section{Correspondence: \\ Khadijah El Ramija \\ Assessment Institute of Agricultural \\ Technology of North Sumatera, \\ Jalan AH Nasution 1B, Medan, \\ Indonesia 20143. \\ Email: khadijahramija@yahoo.co.id}

\section{This is an open-access article} distributed under the CC BY License. (c) 2021 The Authors. Agromet.

\begin{abstract}
A B S T R A C T
El Niño Southern Oscillation (ENSO) is a global phenomenon that drives local and regional climate variability. It also affects various sectors in daily life, including agriculture. Influence of El Niño is well documented in literatures and generally it gives detrimental effects on agriculture. But, our understanding on local impact to main crops in Langkat Regency, North Sumatra is limited. This study explored the influence of the 2015/16 El Niño in Langkat Regency particularly on local climate variability, and production of on rice, corn, and soybean. We used daily climate data for 1981-2016 combined with agricultural production for 2010-2016. The onset of rainy season was determined using climate data, and we divided the analysis based on the seasonal zone (ZOM). Then we statistically compared agricultural production of each main crops (rice, corn, soybean) annually to the annual mean production for 2010-2016. The results showed that El Niño shorten a wet season in 2015/16 for all ZOMs, with a decreased rainfall between $7 \%$ to $30 \%$ compared to the normal year. In contrast, agricultural production had risen for $6 \%-16 \%$ due to human interventions during El Niño period. The interventions were comprised of two activities: the use of climate information for agricultural management and expansion of planting area. The findings suggested that climate information will be benefit to society when it is properly used.
\end{abstract}

\section{KEYWORDS}

climate classification, crops productivity, dasarian rainfall, inverse distance weight, seasonal zone

\section{INTRODUCTION}

El Niño and Southern Oscillation (ENSO) phenomenon drives dynamics of climate variability in Indonesia, and it has caused adverse impacts on agriculture (Sun et al., 2017; Surmaini et al., 2018), forest fire (Nurdiati et al., 2021; Taufik et al., 2019, 2017), health (McGregor and Ebi, 2018; Vincenti-Gonzalez et al., 2018), water (Irwandi et al., 2021; Ni et al., 2018), and environment (Lou et al., 2019; Pinker et al., 2017; Zhu et al., 2017). ENSO is an atmosphere-ocean interaction that plays a major role in driving annual climate variations (Li et al., 2019; Yang et al., 2018). ENSO event is caused by the process of atmospheric-ocean interaction in the Pacific region, which changes the direction of atmospheric circulation, ocean current, and climate patterns in Indonesia (Salmayenti et al., 2017). ENSO consists of three phenomena, namely normal condition, El Niño, and La Niña.

During El Niño conditions, sea surface temperature in the East Equatorial Pacific is higher than usual. On the contrary, during La Niña, sea surface temperature in the East Equatorial Pacific is lower than usual. This occurs due to the wind circulation system, the atmospheric movement over the ocean, and sealevel pressure along the equatorial zone (Feng et al., 2018). El Niño delays the onset of wet season and reduces total rainfall amount, while La Niña causes an increased rainfall in Indonesia (Lestari et al., 2019; Supari et al., 2018). 
El Niño has caused a prolonged drought in Indonesia (Taufik et al., 2017). ENSO influences almost all regions of Indonesia except northern Sumatra and parts of Kalimantan (Kurniadi et al., 2021). However, previous study that used a more detailed data on provincial administrative boundaries suggested different results. There was a decrease in rainfall in North Sumatra during an El Niño event (Iskandar et al., 2019). Furthermore, a research conducted in the east coast, east hillside, and highlands of North Sumatra also revealed that rainfall in period December-JanuaryFebruary (DJF), June-July-August (JJA), and SeptemberOctober-November (SON) was decreased during $\mathrm{El}$ Niño phase (Irwandi et al., 2019).

To determine the onset of dry season, BMKG (2016) suggested that the calculation is based on the amount of rainfall in a dasarian (10-days period) which less than $50 \mathrm{~mm}$, followed by another dasarian with similar amount. Meanwhile, the onset of the wet season is determined based on the amount of rainfall in a dasarian equal to or more than $50 \mathrm{~mm}$, also followed by another dasarian with similar amount. The onset of each season can occur earlier, the same as, or later than normal (with normal definition is the common onset period in 1981-2010). Within one month, there are three dasarian. Dasarian I is from the 1st to 10 th days, dasarian II is from the $11^{\text {th }}$ to $20^{\text {th }}$ days, and dasarian III is from the $21^{\text {st }}$ to the end of the month (Giarno et al., 2012).

To achieve sustainable food self-sufficiency, government had optimized the Special Efforts (Upaya Khusus, UPSUS) program aimed to increase production of rice, corn, and soybean (Sari and Sjah, 2016). According to BPTP (2018), this effort had been made through extensification in North Sumatra Province during 2014/2015, 2015/2016 and 2016/2017 planting periods (Table 1). This study aimed to explain the influence of El Niño in 2015/2016 on climate variability, also rice, corn, and soybeans production in Langkat Regency. We argued that El Niño activities tend to adversely impact the agricultural sector, one of which is increasing the potential for crop failure due to drought.

\section{RESEARCH METHODS}

This research was conducted in Langkat Regency, which is a central crop producer in North Su-

Table 1. Additional planting area (LTT) of three main crops commodities during the UPSUS program in North Sumatra Province.

\begin{tabular}{lrrr}
\hline \multirow{2}{*}{ Commodity } & \multicolumn{3}{c}{ Planting Period } \\
\cline { 2 - 4 } & $\mathbf{2 0 1 4 / 1 5}$ & $\mathbf{2 0 1 5 / 1 6}$ & $\mathbf{2 0 1 6 / 1 7}$ \\
\hline Rice & 795,391 & 900,797 & 988,854 \\
\hline Corn & 208,961 & 253,929 & 263,259 \\
\hline Soybean & 5,233 & 5,523 & 4,120 \\
\hline
\end{tabular}

matra Province. Langkat Regency is located in Bukit Barisan highlands, northwestern part of North Sumatra Province. It is geographically located at $03^{\circ} 14^{\prime} 00^{\prime \prime} \mathrm{N}$ to $04^{\circ} 13^{\prime} 00^{\prime \prime} \mathrm{N}$ and $97^{\circ} 51^{\prime} 00^{\prime \prime} E$ to $98^{\circ} 45^{\prime} 00^{\prime \prime} \mathrm{E}$. In 2013 , the administrative area of Langkat Regency covered 23 sub-districts, 240 and 37 villages with a total area of $6,263 \mathrm{~km}^{2}$ or about $8.74 \%$ of North Sumatra Province (BPS, 2019a). Cropping system in Langkat Regency still relies on climate (Nasution and Nuh, 2019), and it was the fourth highest districts on rice production contributing by more than $5 \%$ of the North Sumatra Province of rice production in 2018 (BPS, 2019b).

This research were based on three primary data to analyze the climatic condition of the study area: (i) daily rainfall data obtained from 23 rain gauges (Table 2); (ii) the delineation of seasonal zone (Zona Musim, ZOM) from the Deli Serdang Climatology Station (BMKG, 2016); and (iii) Oldeman climate classification from Sudrajat (2009). The data was then visualized spatially and was used to identify the land suitability for agriculture regarding to the water availability. The point-based rainfall data was converted into spatial data using the inverse distance weight (IDW) interpolation, which is one of the most used deterministic methods to calculate spatial rainfall (Sanusi et al., 2021).

To analyze the impact of El Niño on climate variability, we used daily rainfall data in the period between 1981 and 2016 from the gauges included in Langkat Regency. Based on the daily rainfall, the dasarian rainfall was determined, then it was compared to the normal rainfall data, which was obtained by averaging dasarian rainfall in period of 1981-2010. The comparison was presented in three different seasonal zone during planting period of 2015/2016.

This research used ENSO index data in 20102016 period as an indicator of El Niño activity in the Pacific Ocean, which was retrieved from https://www.esrl.noaa.gov/psd/enso/mei/. The ENSO index is obtained by calculating the average of sea surface temperature anomalies in the Niño 3.4 area $\left(190^{\circ} \mathrm{E}-240^{\circ} \mathrm{E}\right.$ and $\left.5^{\circ} \mathrm{S}-5^{\circ} \mathrm{N}\right)$ according to El Niño definition (Irwandi et al., 2018; Petereit et al., 2018). ENSO intensity is divided into 3 categories; weak, moderate, and strong. Weak El Niño has an ENSO index range of 0.5 to 1 , moderate El Niño has a range of 1 to 2, and strong El Niño has a range of 2 to 3. Similarly, weak La Niña has an ENSO index range of -0.5 to $-1{ }^{\circ} \mathrm{C}$, moderate La Niña has a range of -1 to -2 , and strong La Niña has a range of -2 to -3 (Irwandi et al., 2019; Lam et al., 2019). Lastly, we used the annual production and productivity data of rice, corn, and soy bean commodities in 2010-2016, which were obtained from 
Table 2. List detailed information of the rain gauges in Langkat Regency.

\begin{tabular}{|c|c|c|c|c|c|}
\hline No & Station Name & Subdistrict & Station Number & Latitude $\left({ }^{\circ} \mathrm{N}\right)$ & Longitude $\left({ }^{\circ} \mathrm{E}\right)$ \\
\hline 1 & Sei Curai Utara & Babalan & $12051401 a$ & 3.980 & 98.320 \\
\hline 2 & Bahorok & Bahorok & $12050101 a$ & 3.500 & 98.130 \\
\hline 3 & Batang Serangan & Batang Serangan & $12051901 a$ & 3.604 & 98.032 \\
\hline 4 & Besitang & Besitang & $12051602 a$ & 3.896 & 97.994 \\
\hline 5 & Kwala Begumit & Binjai & $12050501 a$ & 3.670 & 98.450 \\
\hline 6 & Tanjung Jati & Binjai & $12050503 a$ & 3.632 & 98.463 \\
\hline 7 & BPP Brandan Barat & Brandan Barat & $12051801 a$ & 4.076 & 98.285 \\
\hline 8 & Gebang & Gebang & $12051301 a$ & 3.960 & 98.370 \\
\hline 9 & Cempa & Hinai & $12051001 a$ & 3.870 & 98.420 \\
\hline 10 & Kuala & Kuala & $12050301 a$ & 3.537 & 98.386 \\
\hline 11 & Padang Tualang & Padang Tualang & $12051201 a$ & 3.723 & 98.271 \\
\hline 12 & Pulau Kampai & Pangkalan Susu & $12051503 a$ & 4.200 & 98.250 \\
\hline 13 & Pematang Jaya & Pematang Jaya & $12052302 a$ & 4.250 & 98.170 \\
\hline 14 & Tj. Langkat & Salapian & $12050201 a$ & 3.480 & 98.300 \\
\hline 15 & Secanggang & Secanggang & $12050901 a$ & 3.844 & 98.534 \\
\hline 16 & Sei Bingei & Sei Bingei & $12050401 a$ & 3.532 & 98.504 \\
\hline 17 & Brahrang/ Selesai & Selesai & $12050603 a$ & 3.600 & 98.420 \\
\hline 18 & Pardamean & Stabat & $12050701 a$ & 3.695 & 98.416 \\
\hline 19 & Kwala Bingei & Stabat & $12050702 a$ & 3.750 & 98.450 \\
\hline 20 & Kwala Madu & Stabat & $12050703 a$ & 3.730 & 98.440 \\
\hline 21 & Turangi Lama & Salapian & $12050205 a$ & 3.450 & 98.280 \\
\hline 22 & Kwala Nibung & Bahorok & $12050106 a$ & 3.506 & 98.265 \\
\hline 23 & Pancur Ridho & Salapian & $12050204 a$ & 3.502 & 98.284 \\
\hline
\end{tabular}

the Agriculture and Forestry Service of Langkat Regency (BPS, 2017). Both data were then compared to both period of before and after the extensification program (UPSUS), as well as the ENSO classification. From the analysis, we expected to find out whether the UPSUS program was be able to overcome the potential failure of those three commodities during the El Niño condition.

\section{RESULTS AND DISCUSSIONS}

\section{Climatic Condition in Langkat Regency}

Based on the annual rainfall in Langkat Regency (Figure 1a), most districts received more than 1,500 $\mathrm{mm} /$ year. According to the criteria for paddy field suitability proposed by Suheri et al. (2018), the study area mostly belonged to suitable (S1-S3) for rice cultivation in terms of the annual rainfall. The pattern of rainfall distribution followed the topography that the high altitude will lead to more rainfall. The highest annual rainfall, which reached more than $4,500 \mathrm{~mm}$, occurred in Bohorok District and its surrounding as it is placed in the Bukit Barisan highlands. The average rainfall then gradually decreased toward northern part of Langkat in response to the changing of topographic surface, which become low land area. In the low land area, the annual rainfall ranged from 1,500-2,500 mm.

On monthly scale, average rainfall in Langkat varied between $100-300 \mathrm{~mm}$ (Figure $1 \mathrm{~b}$ ). The rainfall pattern typically followed equatorial patterns, which consist of dry season in January-April and June-July, and wet season in May, August-December. The lowest rainfall occurred in February $(104 \mathrm{~mm})$, while the highest was in September (306 mm). In Langkat, rainfall plays an essential role in agricultural practice as most of rice fields were rainfed and only a few applied irrigation system (Sembiring et al., 2020).

The identified spatial rainfall had similar pattern to the distribution of Oldeman' climate classification and seasonal zone. In high rainfall region, the Oldeman classification was synchronized with $A 1$ and $B 1$ type (Figure $1 \mathrm{c}$ ). Area with both $\mathrm{A}$ and $\mathrm{B}$ types of climate are identified as suitable to produce rice continuously. Meanwhile, coastal area in the northern part of Langkat, which was associated with low rainfall, mostly belong to D1 class, and varied with D2, E1, E2 and E3 class in some places. In the area between high and lowlands, it 

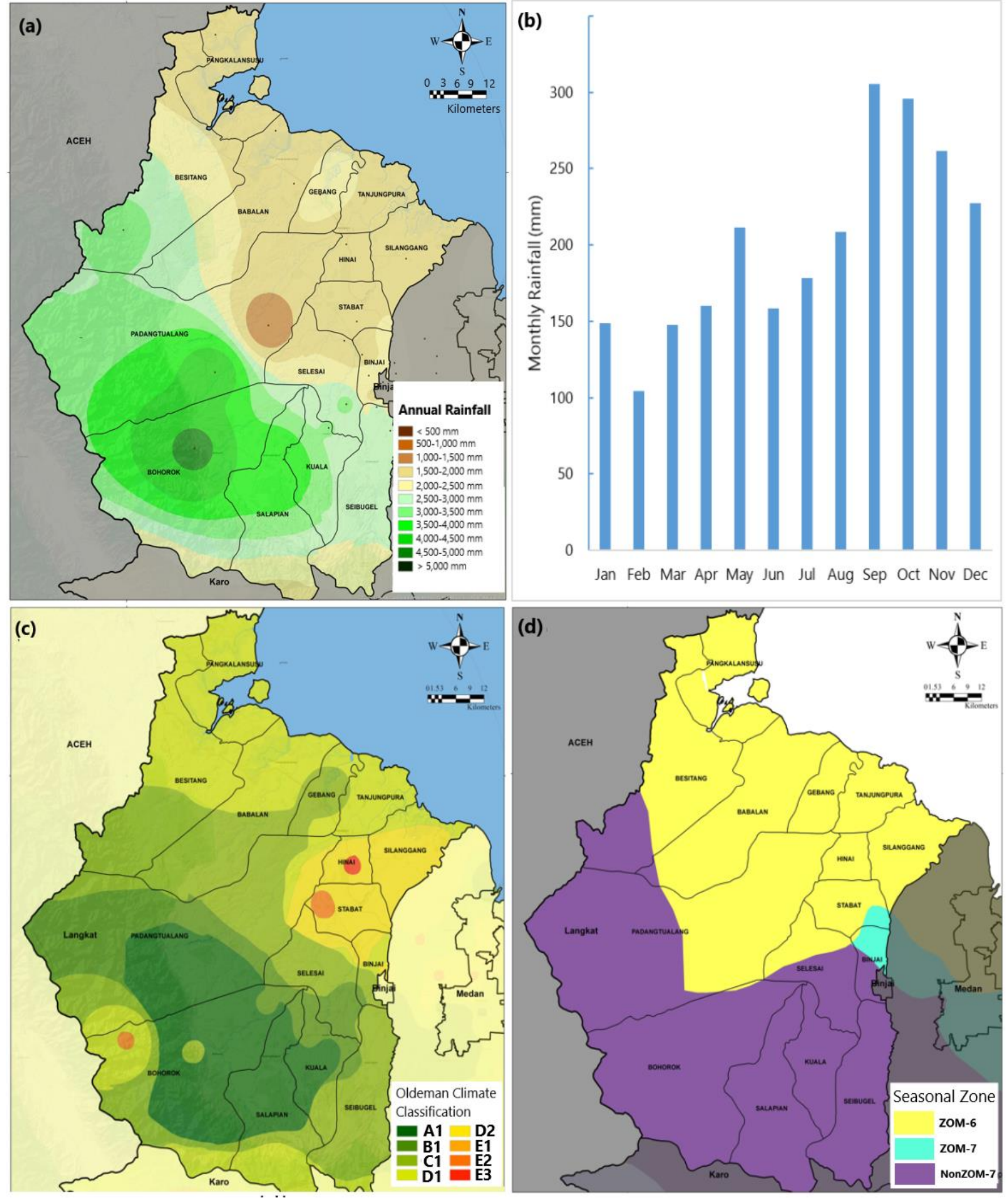

Figure 1. Climatic condition in Langkat Regency: (a) average annual rainfall distribution, (b) monthly rainfall, (c) Oldeman climate classification, and (d) seasonal zone delineation.

was included to $C 1$ type of climate. Those area with Oldeman C, D, E class were identified as suitable for rice combined with secondary crops, such as corn, and soybean cultivation (Harahap et al., 2021).

For the seasonal zone, the high rainfall area was associated with NonZOM-7, while the rest were almost included to ZOM-6 (Figure 1d). Only few parts of southeast Langkat which identified as ZOM-7 area. In terms of the function of ZOM delineation, the NonZOM-7 meant that there is no clear difference between wet and dry season. In Langkat, it was relevant with the fact that those area was place in high altitude 
(Bukit Barisan highlands) and the rain were occurred continuously as combination between monsoon and orographic effect. In contrast, both ZOM-6 and ZOM-7 area mean that the differences between wet and dry season is clear since rainfall in those area was only affected by the monsoonal changes.

Compared to the existing land use in Langkat, agricultural area, which are located on the hillside and east coast region, were very vulnerable to climatic anomalies either de to drought or flood. According to the analysis of flood-prone areas (BMKG, 2014), a significant increased rainfall depth in highland and mountainous areas in Langkat was able to increase possibility for flood in the hillside and coastal regions. This research showed that rainfall had a very significant role on agricultural practices in Langkat.

\section{The Effect of El Niño 2015/2016 on Seasonal Rainfall}

The effect of El Niño on rainfall in Langkat Regency was presented in dasarian time series for 2year, which was 2015 and 2016 (Figure 2). In general, rainfall in both years was lower than that of in normal year (average 1981-2020), particularly in dry season. The difference of average monthly rainfall between $\mathrm{EI}$ Niño event and normal period was varied for each seasonal zone. Despite the amount of rainfall, El Niño also affected the length of seasonal period.

In ZOM-6, first dry season in normal condition occurred in January-April, while the second was in June-mid of July (Figure 2a). The average dasarian rainfall during dry season was about $38 \mathrm{~mm}$. In El Niño 2015, the first dry season was delayed up to 20 days, hence it started in the $3^{\text {rd }}$ dasarian of January and finished in $2^{\text {nd }}$ of May. There was only three dasarians, which had rainfall more than $50 \mathrm{~mm}$ as the first wet period. Based on the theory, the second wet season was started in August yet there were seven (from 15) dasarians, which had rainfall less than $50 \mathrm{~mm}$. The average dasarian rainfall during El Niño event decreased up to a half of its normal. In 2016, the onset of first dry season was in $3^{\text {rd }}$ dasarian of February, delayed more than a month from its normal. The dry season lasted for almost three months, ending in the $1^{\text {st }}$ dasarian of May. The second dry season was faded since there were two dasarians with high amount of rainfall in the middle of July. During the wet season, which was from the end of May until December, there were only seven (from 23) dasarians which included dry period (less than $50 \mathrm{~mm}$ ). Annually, El Niño decreased the rainfall amount of two-year period up to $465 \mathrm{~mm}$ (11\% lower) compared to the normal condition.
In ZOM-7, change of dasarian rainfall in normal condition had similar pattern to that of in ZOM-6, yet the difference between wet and dry season was visually distinct (Figure 2b). Overall, the El Niño condition in both 2015 and 2016 had decreased the rainfall in most dasarian. Of 72 dasarians, there were only 11 dasarians, which rainfall was above normal. The average of dasarian rainfall in normal condition was about $38 \mathrm{~mm}$. In 2015, the first dry season was prolonged more than 2 months, hence the wet season was delayed until the middle of July. The first wet season only occurred in a month, then it was continued by the second dry season started in the middle of August and lasted in October. After having second wet season for a month and a half, December 2015 became the onset for the first dry season in 2016. This dry season was lasted for more than 8 months even there were some dasarians which had high rainfall (more than $60 \mathrm{~mm}$ ). The wet season of 2016 was in mid of August until December. The average dasarian rainfall during dry season throughout El Niño year in ZOM-7 was about $22 \mathrm{~mm}$. This value was higher than that of in ZOM-6. However, in terms of the seasonal length period, ZOM-7 had longer dry season in both years. El Niño phenomena had decreased the amount of the total annual rainfall in ZOM-7 for about $30 \%$ (lower $1283 \mathrm{~mm}$ ) compared to the normal condition.

In NonZOM-7, the amount of rainfall was higher than two previous seasonal zone (Figure 2c). For the normal condition, all the dasarian rainfall were more than $50 \mathrm{~mm}$, while the rainfall pattern still followed the equatorial pattern. In general, El Niño event for both in 2015 and 2016 was only affected the rainfall during dry season. In the first dry season of 2015, the dasarian rainfall was only significant decreased on the $2^{\text {nd }}$ of March and $1^{\text {st }}$ of April, while the second dry season was only lasted for a month started from $3^{\text {rd }}$ of June until $2^{\text {nd }}$ of July. The rest period of 2015 was included to wet period, which had rainfall like its normal condition. The same results showed in 2016, the first dry season had lower dasarian rainfall, compared to the normal condition. The first dry season, from the $3^{\text {rd }}$ of January to $1^{\text {st }}$ April, was $21 \mathrm{~mm}$ in average dasarian rainfall which was only a third of its normal rainfall. The second dry season was disappeared since it was only a dasarian period which had very low rainfall $(3 \mathrm{~mm})$ in between high dasarian rainfall (more than $60 \mathrm{~mm}$ ). The rest dasarian in 2016 was included to wet period, yet it mostly had lower rainfall than that of its normal condition. Overall, the total rainfall for both two years (in 2015-2016) was lower than the normal up to 446 $\mathrm{mm}$ or $7 \%$. 

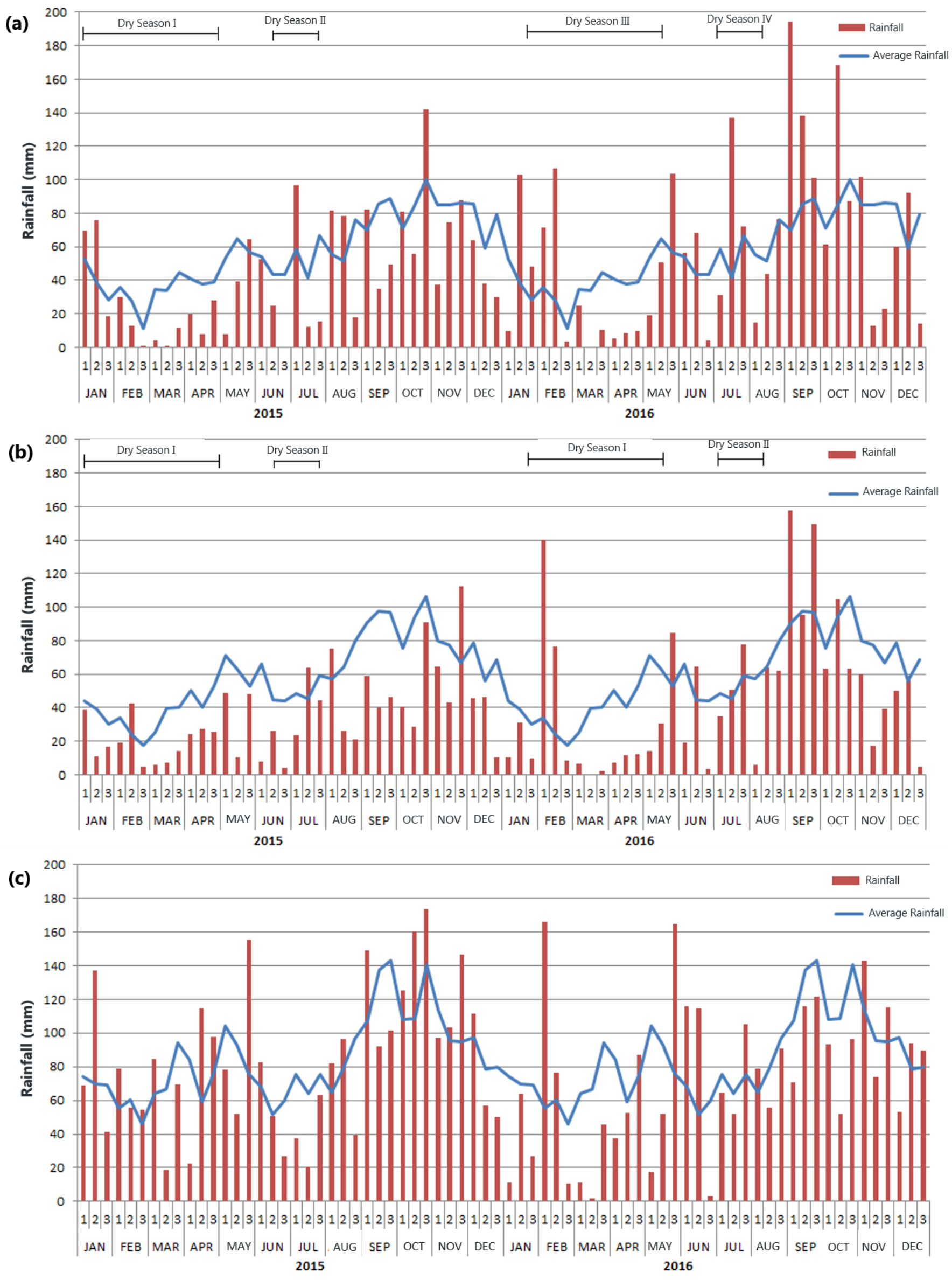

Figure 2. Plot time series of dasarian rainfall for period 2015-2016 in each seasonal zone: (a) ZOM-6, (b) ZOM-7, and (c) NonZOM-7. The blue line is the normal rainfall, which is average of dasarian rainfall for period 19812010. 


\section{Effect of ENSO on Main Crops Productivity}

Based on the comparison of productivity in the period between 2010-2016, the cold phase of ENSO (La Niña) has caused the decrease productivity of all crops, while the warm phase (El Niño) has increased on rice and corn productivity (Table 3). For rice, strong El Niño condition in 2015 resulted the highest productivity during the given period, which was more than 6.4 tons/ha. The rice productivity in the normal and La Niña condition were always lower than that of the average value over the given period. During the normal phase of ENSO, the productivity of rice was varied between 5.8-6.0 tons/ha, and the lowest productivity was found in 2013 as its value was 5.82 tons/ha.

For corn, the lowest productivity was found when it was in La Niña condition, which was less than 6 tons/ha. In normal year, corn productivity varied between 6.2-6.4 tons/ha. The highest corn productivity, which was about $10 \%$ higher than the average value, occurred in 2015 when strong El Niño event happened. For soybean productivity, the value ranged from 1.421.59 tons/ha. In general, soybean productivity was not affected by ENSO events since there was a slightly different value for each phase. Only when it was La Niña that soybean productivity was lower than normal.

\section{Main Crops Production in Langkat Regency}

Based on the production data for each crop, UPSUS program has provenly raised crop production in Langkat Regency (Table 4). For rice, the production was about 0.45 million tons. Comparison between before (2010-2014) and after (2015-2016) The extensification program raised the production up to 60,000 tons. In strong El Niño 2015, beside the high productivity of the rice plant, the high production was also affected by the extensification program. The increase of rice production during El Niño event (2015/16) was about $9.3 \%$.
For corn, during El Niño, its production was higher than the average value, whereas in the previous phase ENSO (La Niña and Normal) the production was mostly below its average. The lowest corn yield was in La Niña condition, which was about $30 \%$ lower $(101,000$ tons) than average value. In El Niño, although the corn productivity in 2016 was lower than that of in 2015, the annual production was far higher (about 180,000 tons). This increasing corn's yield was probably a result of the UPSUS program on expanding field. The increase of corn production during El Niño event (2015/16) was about $15.8 \%$.

For soybean, the average production was varied during the period of analysis around 881-2,784 tons. Compared to the productivity of soybean, the production was related with the area of planting since the annual productivity was not significant different among other years. The extensification program seemed successfully increase the production in 2016 up to 2,098 tons, after having low yield in 2015, which was $23 \%$ less than the average (1,193 tons). The increase of soybean production during El Niño event $(2015 / 16)$ was about $6 \%$.

The implementation of UPSUS was found to be able to optimize crop production. Busyra (2016) reported that there was an increase in rice yield in Tanjung Jabung Timur Regency following implementation of UPSUS programs. The programs include intensification in the form of adding the number of seeds, fertilizer dosage, and the number of agricultural machinery, also rice field expansion. The results showed that the rice field expansion had a significant effect in the increased rice yield by more than $5 \%$, increased seed subsidies stimulus by $6 \%$ resulted in increased rice yield by $30 \%$, increasing fertilizer subsidies by $6 \%$ resulted in increasing rice yield by $0.3 \%$, and increasing machinery assistance stimulus by $6 \%$ resulted in increased rice yield by $10 \%$.

Table 3. The productivity of three main crops in Langkat Regency in the period between 2010 and 2016.

\begin{tabular}{|c|c|c|c|c|c|c|c|}
\hline \multirow{2}{*}{ Year } & \multirow{2}{*}{ ENSO Category* } & \multicolumn{3}{|c|}{ Productivity (tons/ha) } & \multicolumn{3}{|c|}{ Percentage of Deviation** (\%) } \\
\hline & & Rice & Corn & Soybean & Rice & Corn & Soybean \\
\hline 2010 & Strong La Niña & 5.96 & 5.60 & 1.45 & $(0.88)$ & $(12.34)$ & $(2.36)$ \\
\hline 2011 & La Niña & 5.88 & 5.71 & 1.47 & $(2.20)$ & $(10.60)$ & $(1.09)$ \\
\hline 2012 & Normal & 5.93 & 6.68 & 1.53 & $(1.43)$ & 4.46 & 2.81 \\
\hline 2013 & Normal & 5.82 & 6.43 & 1.45 & $(3.24)$ & 0.66 & $(2.57)$ \\
\hline 2014 & Normal & 6.01 & 6.25 & 1.59 & $(0.02)$ & $(2.20)$ & 6.57 \\
\hline 2015 & Strong El Niño & 6.46 & 7.08 & 1.42 & 7.50 & 10.79 & $(4.45)$ \\
\hline 2016 & El Niño & 6.03 & 6.98 & 1.50 & 0.26 & 9.23 & 1.08 \\
\hline Mean & & 6.01 & 6.39 & 1.49 & & & \\
\hline
\end{tabular}

note: *based on the dominant ENSO index value throughout the year. ${ }^{* *}$ difference gap between the year's value and the 2010-2016 average value. The highlighted row means that UPSUS program was applied. 
Table 4. The annual yield of three main crops in Langkat Regency in period 2010-2016.

\begin{tabular}{|c|c|c|c|c|c|c|}
\hline \multirow[b]{2}{*}{ Year } & \multicolumn{2}{|c|}{ Rice } & \multicolumn{2}{|c|}{ Corn } & \multicolumn{2}{|c|}{ Soybean } \\
\hline & Yield (tons) & $\begin{array}{c}\text { Percent of } \\
\text { Deviation* }(\%)\end{array}$ & Yield (tons) & $\begin{array}{c}\text { Percent of } \\
\text { Deviation* }(\%)\end{array}$ & Yield (tons) & $\begin{array}{c}\text { Percent of } \\
\text { Deviation* (\%) } \\
\end{array}$ \\
\hline 2010 & 400,273 & (10.99) & 131,033 & $(9.10)$ & 2,080 & 33.98 \\
\hline 2011 & 444,565 & $(1.15)$ & 101,047 & (29.90) & 881 & $(43.27)$ \\
\hline 2012 & 473,117 & 5.20 & 129,545 & (10.13) & 922 & $(40.62)$ \\
\hline 2013 & 452,634 & 0.65 & 184,666 & 28.11 & 2,784 & 79.33 \\
\hline 2014 & 394,399 & (12.30) & 128,772 & (10.66) & 910 & $(41.40)$ \\
\hline 2015 & 511,729 & 13.8 & 147,697 & 2.5 & 1,193 & (23.1) \\
\hline 2016 & 471,289 & 4.8 & 186,244 & 29.2 & 2,098 & 35.1 \\
\hline Mean & 449,715 & & 144,143 & & 1,553 & \\
\hline
\end{tabular}

note: *difference gap between the year's value and the 2010-2016 average value. The highlighted row means that UPSUS program was applied.

Wijaya et al. (2016) also stated the same thing, wherein the productivity of rice after the UPSUS Pajale program in Subak Gadungan Delod Village, Tabanan Regency was increased to 5.44 tons/ha. The increase in rice yield after UPSUS Pajale program was 0.93 tons/ha and exceeded the target set by the government $(0.3$ ton/hectare). Apart from several programs mentioned, Estiningtyas and Rahman (2020) also reported several actions of human interventions to optimize food farming system. Those include providing alternative water sources, implementing a planting calendar, increasing the capacity and resilience of the production system through the cultivation approach, and also improving human and institutional capacity.

\section{CONCLUSIONS}

Langkat Regency is one of the central productions of rice, corn, and soybean, in North Sumatera. The yield of those crops was hypothetically affected by the climate variability induced by ENSO. To prevent insufficiency those crops supply during El Niño events (2015/16), government had applied the extensification program (UPSUS) in period 2014-2017. Langkat Regency was mostly identified as suitable area for rice, corn, and soybean cultivation, in terms of its annual rainfall distribution, and climate classification. Our findings showed that ENSO phase in 2015/16 (El Niño) decreased rainfall for all seasonal zones, by $7 \%$ to $30 \%$. The efficiency of UPSUS program was analyzed by comparing crops productivity and yield for each year to the average value during 2010-2016. Our finding revealed that crops productivity during El Niño event were just slightly different to the normal condition. However, the agricultural production had risen for $6 \%-$ $16 \%$ due to human interventions: the use of climate information for agricultural management and expansion of planting area.

\section{ACKNOWLEDGEMENTS}

This research was funded by the Research Institute for Agricultural Technology, North Sumatra Province and Deli Serdang Climatology Station. The authors thank to the Department of Agriculture for Food Crops and Horticulture of North Sumatra Province and the Department of Agriculture of Langkat Regency for providing data used in this research. We also thank to two anonymous reviewers for their valuable comments on the manuscript.

\section{REFERENCES}

BMKG, 2016. Prakiraan Musim Hujan 2016 di Sumatera Utara. Badan Meteorologi Klimatologi dan Geofisika, Deli Serdang.

BMKG, 2014. Atlas Rawan Banjir Kabupaten Langkat Provinsi Sumatera Utara. Badan Meteorologi Klimatologi dan Geofisika, Jakarta.

BPS, 2017. Langkat Regency in Figures 2017. Statistics of Langkat Regency.

BPS, 2019a. Kabupaten Langkat Dalam Angka 2019. Badan Pusat Statistik, Langkat.

BPS, 2019b. Provinsi Sumatera Utara Dalam Angka 2019 Badan Pusat Statistik, Medan.

Busyra, R.G., 2016. Dampak program upaya khusus (upsus) padi jagung kedelai (pajale) pada komoditas padi terhadap perekonomian Kabupaten Tanjung Jabung Timur. Jurnal MeA (Media Agribisnis) 1, 5 http://dx.doi.org/10.33087/mea.v1i1.5

Estiningtyas, W., Rahman, A., 2020. Determinant Factor of Food Farming Vulnerability in Banten Province To Support Climate Change Adaptation. Agromet 34, 129-142.

Feng, M., Zhang, N., Liu, Q., Wijffels, S., 2018. The Indonesian throughflow, its variability and 
centennial change. Geoscience Letters 5, 3. https://doi.org/10.1186/s40562-018-0102-2

Giarno, Dupe, Z.L., Mustofa, M.A., 2012. Kajian Awal Musim Hujan dan Awal Musim Kemarau di Indonesia. Jurnal Meteorologi dan Geofisika 13, 113. http://dx.doi.org/10.31172/jmg.v13i1.113

Harahap, I.S., Matondang, I.Z., Suryanto, Indah, E.K., Fitri, I., 2021. Mapping Climate Classification of Oldeman in Agricultural Resources Management in South Tapanuli District. IOP Conference Series: Materials Science and Engineering 1156, 012002. https://doi.org/10.1088/1757899x/1156/1/012002

Irwandi, H., Pusparini, N., Ariantono, J., Kurniawan, R., Tari, C., Sudrajat, A., 2018. The Influence of ENSO to the Rainfall Variability in North Sumatra Province. Presented at the IOP Conference Series: Materials Science and Engineering, IOP Publishing, p. 012055. https://doi.org/10.1088/1757899X/335/1/012055

Irwandi, H., Rosid, M.S., Mart, T., 2021. The effects of ENSO, climate change and human activities on the water level of Lake Toba, Indonesia: a critical literature review. Geoscience Letters 8, $21 . \quad$ https://doi.org/10.1186/s40562-02100191-x

Irwandi, H., Syamsu Rosid, M., Mart, T., 2019. Identification of the El Niño Effect on Lake Toba's Water Level Variation. IOP Conference Series: Earth and Environmental Science 406, 012022 . https://doi.org/10.1088/17551315/406/1/012022

Kurniadi, A., Weller, E., Min, S.-K., Seong, M.-G., 2021. Independent ENSO and IOD impacts on rainfall extremes over Indonesia. International Journal of Climatology 41, 3640-3656. https://doi.org/10.1002/joc.7040

Lam, H.C.Y., Haines, A., McGregor, G., Chan, E.Y.Y., Hajat, S., 2019. Time-series study of associations between rates of people affected by disasters and the El Niño Southern Oscillation (ENSO) cycle. International journal of environmental research and public health 16, 3146. https://doi.org/10.3390/ijerph16173146

Lestari, S., King, A., Vincent, C., Karoly, D., Protat, A., 2019. Seasonal dependence of rainfall extremes in and around Jakarta, Indonesia. Weather and Climate Extremes 24, 100202. https://doi.org/10.1016/j.wace.2019.100202

Li, X., Hu, Z.-Z., Huang, B., 2019. Contributions of Atmosphere-Ocean Interaction and LowFrequency Variation to Intensity of Strong El
Niño Events since 1979. Journal of Climate 32, 1381-1394. https://doi.org/10.1175/JCLI-D18-0209.1

Lou, S., Yang, Y., Wang, H., Lu, J., Smith, S.J., Liu, F., Rasch, P.J., 2019. Black Carbon Increases Frequency of Extreme ENSO Events. Journal of Climate 32, 8323-8333. https://doi.org/10.1175/JCLI-D19-0549.1

McGregor, G.R., Ebi, K., 2018. El Niño Southern Oscillation (ENSO) and Health: An Overview for Climate and Health Researchers. Atmosphere 9. https://doi.org/10.3390/atmos9070282

Nasution, M.I., Nuh, M., 2019. Kajian Iklim Berdasarkan Klasifikasi Oldeman di Kabupaten Langkat. JISTech (Journal of Islamic Science and Technology) https://doi.org/10.30829/jistech.v3i2.3157

Ni, S., Chen, J., Wilson, C.R., Li, J., Hu, X., Fu, R., 2018. Global Terrestrial Water Storage Changes and Connections to ENSO Events. Surveys in Geophysics 39, 1-22. https://doi.org/10.1007/s10712-017-9421-7

Nurdiati, S., Sopaheluwakan, A., Septiawan, P., 2021. Spatial and Temporal Analysis of El Niño Impact on Land and Forest Fire in Kalimantan and Sumatra. Agromet 35, 1-10. https://doi.org/10.29244/j.agromet.35.1.1-10

Petereit, J., Saynisch, J., Irrgang, C., Weber, T., Thomas, M., 2018. Electromagnetic characteristics of ENSO. Ocean Science 14, 515-524. https://doi.org/10.5194/os-14-515-2018

Pinker, R.T., Grodsky, S.A., Zhang, B., Busalacchi, A., Chen, W., 2017. ENSO impact on surface radiative fluxes as observed from space. Journal of Geophysical Research: Oceans 122, 7880-7896.

https://doi.org/10.1002/2017JC012900

Salmayenti, R., Hidayat, R., Pramudia, A., 2017. Rainfall prediction using Artificial Neural Network. Agromet 31, 11-21. https://doi.org/10.29244/j.agromet.31.1.11-21

Sanusi, A.R., Taufik, M., Santikayasa, I.P., 2021. The Use of Weather Research and Forecasting Model to Predict Rainfall in Tropical Peatland: 1. Model Parameterization. Agromet 35, 49-59. https://doi.org/10.29244/j.agromet.35.1.49-59

Sari, M., Sjah, T., 2016. Implementation of Special Program of Pajale (Rice, Corn and Soybean) in Terara District, East Lombok Regency. International Research Journal of Management, IT and Social Sciences 3, 49-60.

Sembiring, R., Asda, C., Dewi, R., Ananta, A., Pulungan, M., 2020. Development of drilling well irrigation to meet water needs in the rainfall of 
Ramija et al./Agromet 35 (2): 98-107, 2021

Sambirejo village, Kabupaten Langkat. ABDIMAS TALENTA: Jurnal Pengabdian Kepada Masyarakat $\quad 5, \quad 46-51$. https://doi.org/10.32734/abdimastalenta.v5i1. 4024

Sudrajat, A., 2009. Pemetaan klasifikasi iklim Oldeman dan Schmidth-Fergusson sebagai upaya pemanfaatan sumberdaya iklim dalam pengelolaan sumberdaya alam di Sumatera Utara. Universitas Sumatera Utara.

Suheri, N.A., Mujiyo, Widijanto, H., 2018. Land suitability evaluation for upland rice in Tirtomoyo District, Wonogiri Regency, Indonesia. SAINS TANAHJournal of Soil Science and Agroclimatology 15 , 46-53. https://doi.org/10.15608/stjssa.v15i1.21670

Sun, P., Zhang, Q., Cheng, C., Singh, V.P., Shi, P., 2017. ENSO-induced drought hazards and wet spells and related agricultural losses across Anhui province, China. Natural Hazards 89, 963-983. https://doi.org/10.1007/s11069-017-3002-4

Supari, Tangang, F., Salimun, E., Aldrian, E., Sopaheluwakan, A., Juneng, L., 2018. ENSO modulation of seasonal rainfall and extremes in Indonesia. Climate Dynamics 51, 2559-2580. https://doi.org/10.1007/s00382-017-4028-8

Surmaini, E., Susanti, E., Sarvina, Y., Syahputra, M.R., 2018. Development of Early Detection Method for Drought and Flood on Rice Paddy. Agromet 32 , 81-92. https://doi.org/10.29244/j.agromet.32.2.81-92

Taufik, M., Torfs, P.J.J.F., Uijlenhoet, R., Jones, P.D., Murdiyarso, D., Van Lanen, H.A.J., 2017. Amplification of wildfire area burnt by hydrological drought in the humid tropics.
Nature Climate Change 7, 428-431. https://doi.org/10.1038/nclimate3280

Taufik, M., Veldhuizen, A.A., Wösten, J.H.M., van Lanen, H.A.J., 2019. Exploration of the importance of physical properties of Indonesian peatlands to assess critical groundwater table depths, associated drought and fire hazard. Geoderma 347, 160-169. https://doi.org/10.1016/j.geoderma.2019.04.0 01

Vincenti-Gonzalez, M.F., Tami, A., Lizarazo, E.F., Grillet, M.E., 2018. ENSO-driven climate variability promotes periodic major outbreaks of dengue in Venezuela. Scientific Reports 8, 5727. https://doi.org/10.1038/s41598-018-24003-z

Wijaya, I.G.M.A.S., Widyantara, I.W., Dewi, I.A.L., 2016. Efektivitas Alokasi Input Usahatani Padi dalam Program Upsus Pajale di Subak Gadungan Delod Desa, Desa Gadungan, Kabupaten Tabanan. JAA 165305.

Yang, S., Li, Z., Yu, J.-Y., Hu, X., Dong, W., He, S., 2018. El Niño-Southern Oscillation and its impact in the changing climate. National Science Review 5, 840-857. https://doi.org/10.1093/nsr/nwy046

Zhu, Q., Peng, C., Ciais, P., Jiang, H., Liu, J., Bousquet, P., Li, S., Chang, J., Fang, X., Zhou, X., Chen, H., Liu, S., Lin, G., Gong, P., Wang, M., Wang, H., Xiang, W., Chen, J., 2017. Interannual variation in methane emissions from tropical wetlands triggered by repeated El Niño Southern Oscillation. Global Change Biology 23, 47064716. https://doi.org/10.1111/gcb.13726 